\title{
Nutrition in the first 6 months of life - current challenges
}

\author{
Alimentația în primele 6 luni de viață - provocări actuale \\ Vlad DIMA ${ }^{1}$, Cornelia PREDA², Anca SIMIONESCU ${ }^{3,4}$ \\ ${ }^{1}$ Departamentul Neonatologie, Spitalul Clinic Filantropia, București, România \\ ${ }^{2}$ Departamentul Neonatologie, Spitalul Sanador, București, România \\ ${ }^{3}$ Universitatea de Medicină și Farmacie „Carol Davila“,București, România \\ ${ }^{4}$ Departamentul Obstetrică-Ginecologie, Spitalul Clinic Filantropia, București, România
}

\begin{abstract}
From the moment of birth, the diet must aim an optimal development of the full-term, healthy newborn, and the best known option until now is the breast milk. Studies have consistently highlighted the benefits of natural nutrition, emphasizing its nutritional qualities but also its role in developing immunity for the newborn.

A curent challenge is the moment of initiating food diversification, with recommendations indicating ages between 4 and 6 months. Therefore, an analysis of existing recommendations should be linked to studies on the onset of food allergies with the initiation of diversification.

There are also cases in which the natural diet cannot be achieved, in these situations the administration of milk formulas is required. Infant mill formulas have evolved a lot in terms of quality and composition, approaching the breast milk, but they can not be considered equal to it.
\end{abstract}

Keywords: lapte de sân, alergii alimentare, nutriție, dezvoltare optimă, formule de lapte

\section{REZUMAT}

Incă de la momentul nașterii, alimentația trebuie să țintească o dezvoltare optimă a nou-născutului la termen, sănătos, iar cea mái bună variantă cunoscută până la momentul de față este laptele de sân. Studiile efectuate evidențiază în mod constant beneficiile alimentației naturale, accentuând calitățile nutritive ale acestuia, dar și rolul său în dezvoltarea imunității pentru nou-născut.

O provocare de actualitate o reprezintă momentul inițierii diversificării alimentației, existând recomandări care indică vârste între 4 și 6 luni. De aceea, o analiză a recomandărilor ecistente trebuie corelată cu studiile referitoare la declanșarea alergiilor alimentare odată cu inițierea diversificării.

Există și cazuri în care alimentația naturală nu poate fi realizată, în aceste situații impunându-se administrarea de formule de lapte. Acestea au evoluat mult din punctul de vedere al calității și compoziției, apropiindu-se de laptele de sân, fără însă a putea fi considerate egalele acestuia.

Cuvinte cheie: breast milk, food allergy, nutrition, optimal development, milk formula 


\section{INTRODUCERE}

Este cunoscut că alăptarea exclusivă la sân (EBF) este standardul de aur pentru nutriție în primele 6 luni de viață și nu este necesară administrarea de alte lichide sau solide, cu excepția vitaminelor, a suplimentelor minerale și a medicamentelor. Pentru unii nou-născuți, este necesară includerea formulelor de lapte ca hrană complementară (CF). OMS recomandă EBF pentru 6 luni, urmată de introducerea CF alături de alăptare. Această recomandare s-a bazat pe luarea în considerare a duratei optime a EBF și, întrucât formulele pentru sugari sunt definite de OMS ca fiind CF, nu a luat în considerare vârsta optimă pentru introducerea alimentelor solide la sugarii cu formulă (1).

În 2001, Organizația Mondială a Sănătății și-a revizuit recomandarea pentru EBF timp de 6 luni și alăptarea parțială după aceea. Recomandările experților au subliniat că se aplică mai degrabă populațiilor decât persoanelor și că mamele care nu au putut sau nu doresc să respecte această recomandare ar trebui, de asemenea, să fie sprijinite pentru a optimiza nutriția sugarului (2).

Majoritatea specialiștilor în domeniu subliniază importanța furnizării unor surse bune de fier în timpul CF, deși recomandările specifice variază în funcție de populație și de riscul de deficit de fier. Recunoscând că sugarii consumă alimente și diete, mai degrabă decât nutrienți individuali, unele țări europene au transpus recomandările privind consumul de nutrienți pentru sugari și copii mici în ghiduri dietetice bazate pe alimente pentru a oferi părinților indicații asupra alimentelor adecvate vârstei pentru a satisface nevoile dietetice $(3,4)$.

\section{LAPTELE MATERN ÎN PRIMELE 6 LUNI DE VIAȚĂ}

Laptele matern uman este o matrice complexă, cu o compoziție generală de $87 \%$ apă, 3,8\% grăsimi, 1,0\% proteine și $7 \%$ lactoză. Grăsimea și lactoza furnizează $50 \%$, respectiv $40 \%$ din energia totală a laptelui (5). Cu toate acestea, compoziția laptelui matern uman este dinamică și se schimbă în timp, adaptându-se nevoilor în schimbare ale sugarului în creștere. De exemplu, în timpul fiecărei ședințe de alăptare, laptele care se exprimă mai întâi este mai subțire, cu un conținut mai mare de lactoză, care satisface setea unui bebeluș, urmat de laptele mai cremos, cu un conținut mult mai mare de grăsimi pentru nevoile de hrană ale bebelușului. Variațiile sunt, de asemenea, prezente în funcție de etapa de alăptare (vârsta sugarului), dieta maternă, sănătatea maternă și expunerea la mediu. În timpul lactației timpurii, conținutul de proteine din laptele uman variază de la 1,4-1,6 g/100 ml, la 0,8-1,0 g/100 ml după trei până la patru luni de lactație, la 0,7$0,8 \mathrm{~g} / 100 \mathrm{ml}$ după șase luni $(5,6)$. Conținutul de grăsime variază semnificativ în funcție de dieta maternă și este, de asemenea, legat pozitiv de creșterea în greutate în timpul sarcinii.

După multe studii despre nutriție, OMS a concluzionat că EBF în primele 6 luni, în cazul mamelor bine hrănite, poate satisface nevoile de energie, proteine și majoritatea vitaminelor și mineralelor pentru sugarii sănătoși (în afară de vitamina K în primele săptămâni și vitamina $\mathrm{D}$; ambele pot fi obținute prin suplimentare) $(7,8)$.

Nielsen și colab. au raportat că aportul de lapte a crescut semnificativ între 17 și 26 de săptămâni la sugarii cu EBF, în timp ce conținutul energetic al laptelui matern nu s-a modificat (9).

Laptele matern uman conține cantități adecvate de vitamine pentru a sprijini creșterea sugarului. Copiii alăptați exclusiv primesc aportul minim recomandat de vitamina $\mathrm{D}$ și mult mai mic decât dieta recomandată. Acești sugari sunt expuși riscului de deficit de vitamina D, mineralizare osoasă inadecvată și afecțiuni precum rahitismul. Cu toate acestea, riscul general de deficit de vitamina D la sugarii alăptați este, de asemenea, corelat cu expunerea totală la soare, existând un risc crescut de sinteză insuficientă în climatele cu un index inferior de expunere la soare. Suplimentarea maternă cu 400-2000 UI de vitamina D/zi poate crește nivelul de vitamina $D$ din laptele matern, dar numai o doză mai mare (2000 UI) atinge niveluri satisfăcătoare de $25-\mathrm{OH}$ D3 la sugar (5). Depozitele normale de vitamina D prezente la naștere sunt epuizate în decurs de opt săptămâni. Expunerea la lumina soarelui și suplimentarea cu vitamina $D$ sunt recomandate tuturor sugarilor alăptați.

Vitamina K este esențială pentru coagularea sângelui. Cu toate acestea, doar cantități limitate de vitamina K sunt transferate din placentă la făt. Astfel, un nounăscut are adesea o concentrație extrem de scăzută de vitamina $\mathrm{K}$ și este expus riscului de a dezvolta boli hemoragice imediat după naștere. De aceea, după naștere, se recomandă suplimentarea cu vitamina $K$.

În laptele matern uman, mineralele contribuie la o varietate de funcții fiziologice, devenind părți esențiale ale multor enzime și sunt de importanță biologică pentru molecule și țesuturi. Conținutul de minerale este comparabil între laptele uman și laptele bovin. De-a lungul deceniilor, multe alte componente bioactive au fost identificate în laptele uman, inclusiv hormoni, factori de creștere și factori imunologici (10).

ESPGHAN CoN a raportat că sugarii și copiii mici prezintă un risc crescut de deficit de fier, deoarece creșterea lor rapidă duce la cerințe mari de fier (11).

Depozitele de fier depind de o serie de factori și pot fi optimizate prin alte metode anterioare introducerii $\mathrm{CF}$, incluzând clamparea tardivă a cordonului ombilical 
și suplimentarea cu fier la sugarii cu risc, cum ar fi cei născuți înainte de termen sau cu o greutate redusă la naștere. Indiferent de moment, este important ca primul CF administrat sugarilor care sunt EBF să ofere o sursă bună de fier (1).

\section{PREVENIREA INFECTุIILOR}

EBF prelungit protejează împotriva infecțiilor și ajută la prevenirea spitalizării pentru infecții la sugari în zonele cu populații cu venituri ridicate, cu acces la surse de apă curată.

Studiul cohortei Millennium a arătat că introducerea formulelor pentru sugari, nu a alimentelor solide, a prezis o probabilitate crescută de internare în spital. Riscul lunar de spitalizare nu a fost semnificativ mai mare la cei care au primit solide în comparație cu cei care nu au primit solide (pentru diaree, ajustat OR 1,39, 95\% Cl 0,75-2,59; pentru infecțiile tractului respirator mai scăzut, ajustat OR 1,14, 95\% Cl 0,76-1,70), iar riscul nu a variat semnificativ în funcție de vârsta introducerii în alimentație a solidelor inițiale (12).

\section{PREVENIREA ALERGIILOR}

Există cazuri în care se începe diversificarea mai devreme de 6 luni, continuând în paralel administrarea de lapte matern. Însă în aceste cazuri trebuie ținut cont de temerile referitoare la apariția alergiilor alimentare determinate de introducerea precoce a alergenilor alimentari.

Metaanalizele au concluzionat că există dovezi ale unui risc crescut de alergie dacă se introduc alimente solide înaintea vârstei de 3 până la 4 luni, dar nu există dovezi că întârzierea introducerii alimentelor alergenice peste 4 luni reduce riscul de alergie, pentru sugarii din populația generală și pentru cei cu antecedente familiale de atopie (13). Datele observaționale sugerează, de asemenea, un risc crescut de apariție a alegiilor odată cu introducerea întârziată a anumitor alergeni (14).

Un review de literatură recent și o metaanaliză au concluzionat că există probe de certitudine moderată din 5 studii (1915 participanți) că introducerea timpurie a ouălor la 4 până la 6 luni a fost asociată cu un risc redus de alergie la ouă (raport de risc [RR] 0,56 [IC 95\% $0,36-0,87], p=0,009)$, cu rezultate similare în studiile efectuate la populații cu risc normal, risc ridicat și risc foarte mare de alergie (15).

Introducerea arahidelor mai aproape de vârsta de 4 până la 6 luni a indus la sugari un risc redus de a reacționa la arahide (16).

Au existat dovezi de certitudine scăzute până la foarte scăzute că introducerea timpurie a peștelui în alimentație a fost asociată cu o sensibilizare alergică re- dusă și rinită. Nu au fost identificate asociații între vârsta la introducerea alimentelor alergenice și alte boli alergice sau autoimune (17).

\section{BOALA CELIACĂ}

Pe baza dovezilor disponibile obținute exclusiv din studii observaționale, ESPGHAN CoN a concluzionat că este prudent să se evite atât introducerea timpurie $(<4$ luni), cât și cea târzie (> 7 luni) și introducerea glutenului în timp ce sugarul este încă alăptat, deoarece acest lucru poate reduce nu numai riscul de boală celiacă (CD), ci și diabetul zaharat de tip 1 și alergia la grâu (18). $\mathrm{Cu}$ toate acestea, două studii recente au examinat corelația dintre vârsta la care are loc introducerea glutenului și riscul de a dezvolta autoimunitate pentru CD sau CD în timpul copilăriei la copiii cu risc genetic pentru CD.

ESPGHAN a concluzionat că nici alăptarea și nici alăptarea în timpul introducerii glutenului nu s-au dovedit a reduce riscul apariției CD; glutenul poate fi introdus în dieta sugarului oricând între 4 și 12 luni (19).

Cu toate acestea, cantitățile optime de gluten care trebuie introduse la întărcare nu au fost stabilite. Riscul de inducere a CD printr-o dietă care conține gluten se aplică exclusiv persoanelor care poartă cel puțin una dintre alelele cu risc de CD. Deoarece alelele cu risc genetic nu sunt în general cunoscute la sugar în momentul introducerii alimentelor solide, recomandările se aplică tuturor sugarilor.

La sugarii cu risc crescut de a dezvolta diabet de tip 1 , introducerea glutenului la vârsta $<3$ luni comparativ cu introducerea glutenului la vârsta $>3$ luni a fost asociată cu un risc crescut de autoimunitate pentru diabetul de tip 1, dar după vârsta de 3 luni introducerea glutenului nu a avut niciun efect asupra riscului de a dezvolta diabet de tip 1 (20).

\section{APORTUL DE PROTEINE}

Este esențial să oferim nou-născutului o cantitate optimă de proteine, deoarece un aport insuficient de proteine va genera probleme de sănătate în copilărie: întârzierea creșterii, riscul mai mare de infecții, afectarea cognitivă, moartea cauzată de malnutriția proteinelor.

O altă problemă este aportul excesiv de proteine. în ultimele două decenii, cantitatea de proteine din formula de lapte de lapte complementară a crescut ca urmare a recomandărilor medicale privind aportul optim de proteine (21).

Excesul de proteine va genera o cantitate mai mare de aminoacizi în fluxul sanguin, care va deveni o povară reală pentru rinichii imaturi, modificându-le volumul. Un studiu publicat în 2016 a arătat o corelație liniară 
între cantitatea de proteine primite în primele 6 luni de viață și volumul rinichilor (22).

Aportul mai mare de proteine este responsabil pentru creșterea rapidă și excesivă în greutate.

Două studii de amploare au sugerat creșterea riscului de obezitate ulterior asociat cu introducerea timpurie a solidelor (< 4 luni) și un al treilea studiu de bună calitate a confirmat această asociere la hrănirea cu lapte formulă, dar nu la alăptarea la sugari. Niciunul dintre cele 3 studii de bună calitate nu a furnizat dovezi ale vreunui efect clinic relevant generat de întârzierea introducerii alimentelor solide de la 4 la 6 la > 6 luni (23).

\section{ACIZII GRAȘI POLINESATURAȚI CU LANȚ LUNG (LCPUFA)}

LCPUFA, în principal acidul docosahexaenoic (DHA), joacă un rol important în dezvoltarea creierului. Se știe că nivelul DHA tinde să scadă în perioada diversificării, când scade aportul de lapte matern sau formula suplimentată cu LCPUFA.

Sugarii alăptați care au primit 1 borcan pe zi de alimente de înțărcare care conțin gălbenuș de ou îmbogățit cu DHA au avut o creștere mai mare a acuității vizuale la vârsta de 12 luni decât cei alimentați cu hrană pentru copii. Două studii suplimentare au investigat rolul suplimentării LCPUFA în cazul formulelor de lapte. Sugarii care au primit formula suplimentată cu LCPUFA au avut o acuitate vizuală semnificativ mai bună până la vârsta de 1 an față de cei care au primit formula nesuplimentată cu LCPUFA $(24,25)$.

\section{DEZVOLTAREA COGNITIVĂ}

Efectul pe termen lung al suplimentării formulelor de lapte cu LCPUFA la nou-născuții la termen și prematuri asupra cogniției este extrem de incert și include potențialul de beneficii mari, precum și de prejudicii mari.

Cercetările sugerează că sugarii alăptați exclusiv au capacitate cognitivă mai mare în comparație cu cei hrăniți cu formule de lapte. Lipsa LCPUFA din formulele pentru sugari a fost invocată ca fiind responsabilă pentru aceste diferențe cognitive. Cu toate acestea, până în prezent, nu există dovezi clare din studiile controlate randomizate publicate conform cărora formula pentru sugari suplimentată cu LCPUFA îmbunătățește cunoașterea în comparație cu laptele formulă nesuplimentată. Analizele sistematice ar fi putut să nu detecteze o diferență cognitivă, deoarece s-au concentrat în principal pe măsurătorile timpurii ale cunoașterii, cum ar fi scalele Bayley de dezvoltare a sugarului. Cu toate acestea, măsurătorile timpurii ale cunoașterii nu sunt adecvate pentru a face diferența între abilitățile cognitive potențial afectate de suplimente nutritive și sunt slab predictive pentru evoluția capacității intelectuale la vârsta școlară. Urmărirea mai târziu în copilărie, folosind măsurători mai fiabile ale funcției cognitive, cum ar fi scorurile coeficientului de inteligență (IQ), ar putea fi mai eficientă pentru evidențierea unui efect pozitiv al suplementării cu LCPUFA (26).

\section{FORMULA DE LAPTE COMPLEMENTARĂ CA OPȚIUNE ALTERNATIVĂ}

Decizia de a alăpta este extrem de personală și este adesea influențată de mulți factori. În anumite situații, alăptarea ar putea să nu fie posibilă sau inadecvată, ceea ce justifică o întrerupere a alăptării. La nivel global, doar 38\% dintre sugari sunt alăptați exclusiv (10).

Nutrienții furnizați de formulele pentru sugari și formulele de continuare diferă de cele furnizate de laptele matern în această perioadă - în special în ceea ce privește proteinele și fierul - și, prin urmare, cantitatea teoretică care trebuie furnizată de formula de lapte va varia. Astfel, principala sursă de lapte a sugarului este un factor determinant important al cantității de substanțe nutritive care sunt necesare pentru dezvoltare.

Cerințele dietetice relativ ridicate pot să nu fie realizabile în practică fără utilizarea alimentelor fortificate, a formulelor suplimentate cu fier sau a suplimentelor de fier.

Regulamentul recent actualizat al FDA (Food and Drug Administration) cu privire la bunele practici de fabricație pentru formulele de lapte pentru sugari, 21 CFR 106.96, impune, printre altele, ca formulele să satisfacă factorii de calitate ai creșterii fizice normale și o calitate biologică suficientă a componentei proteice (cantități adecvate de proteine într-o formă care poate fi utilizată de sugari). Formulele pentru sugari sunt destinate numai sugarilor sănătoși fără probleme medicale sau dietetice. Procesul de fabricație este foarte strict reglementat și monitorizat pentru a îndeplini criteriile de calitate naționale și internaționale $(27,28,29)$.

Este foarte important să se utilizeze o formulă de lapte pentru sugari cu o compoziție cât mai apropiată de compoziția laptelui matern uman. Un aport inadecvat de nutrienți în primele luni de viață poate genera o programare metabolică modificată. Trebuie să înțelegem că ADN-ul singur nu este cheia pentru o dezvoltare optimă a bebelușului. Nutriția și factorii ambientali pot modifica evoluția corpului uman. Căutând exemple similare în natură, putem discuta despre albine: o larvă a albinei poate ajunge o albină lucrătoare dacă larva primește o dietă mixtă sau larva poate deveni o albină matcă dacă primește doar lăptișor de matcă.

O compoziție excesivă de proteine din formula de lapte poate duce la creșterea nivelului de aminoacizi care eliberează insulină, la un nivel crescut de insulină și IGF-1, rezultând o creștere rapidă a greutății corporale și depozite de grăsime crescute. 
Probioticele joacă, de asemenea, un rol important într-o nutriție adecvată în primele luni de viață. Este bine cunoscut faptul că laptele uman conține prebiotice și probiotice, acționând ca un simbiotic. Este necesar să menționăm că Lactobacillus și Bifidobacterium au fost identificate ca „bacterii principale“ pentru o floră intestinală sănătoasă. Microbiomul laptelui matern este mai variat și diferă de la mamă la mamă. Există mai multe studii care au arătat un rol important al microbiotei intestinale pentru sănătatea organismului uman în curs de dezvoltare: protecție împotriva agenților patogeni, sinteza vitaminelor, dezvoltarea sistemului imunitar, stimularea angiogenezei intestinale, ajustarea stocării grăsimilor, producerea de acizi grași cu lanț scurt, fermentarea fibrelor alimentare, modularea sistemului nervos central („axa intestin-creier“) (30).

Microbiota intestinală comunică cu creierul prin diferite "canale" (semnale neuronale (fibre nervoase senzitive), hormoni (de ex. GLP), citokine (neurotransmițători, mediatori, de exemplu interleukine, interferoni) și metaboliți microbieni (efect benzodiazepinic -relaxant muscular, sedativ). Alterarea diversității microbiomului intestinal are un impact asupra funcției creierului și se dovedește tot mai mult a fi un factor de risc pentru tulburările neurologice și psihiatrice.

Microbiota intestinală în sine este extrem de activă din punct de vedere metabolic și o proporție semnificativă a metaboliților circulanți se datorează, probabil, implicării microbiene. Acești metaboliți pot pătrunde în creier prin fluxul sanguin sau pot activa alte canale de comunicare.

Acizii grași microbiotici cu lanț scurt pot elibera hormoni intestinali, cum ar fi peptidele asemănătoare glucagonului (GLP - un hormon produs în intestin care joacă un rol în metabolismul zahărului), care nu numai că reglează apetitul, ci și influențează starea emoțională (31).

Deci, pentru a fi cât mai aproape de laptele matern, formula de lapte pentru sugari ar trebui să conțină prebiotice și probiotice.

Vitamina D este, de asemenea, necesară ca standard în formula de lapte, dat fiind faptul că suplimentarea vitaminei $D$ este o practică curentă pentru sugari. Sugarii hrăniți cu formule au adesea concentrații serice mai mari de metaboliți ai vitaminei $D$ decât sugarii alăptați (10).

Formula pentru sugari pe bază de lapte de vacă conține uleiuri vegetale adăugate, vitamine, minerale și fier pentru consumul celor mai mulți nou-născuți sănătoși la termen. Potrivit Academiei Americane de Pediatrie, sugarii cu vârsta sub un an nu ar trebui hrăniți cu lapte de vacă crud, nemodificat sau nepasteurizat ca înlocuitor al laptelui uman sau al formulelor pentru sugari. În plus, laptele de vacă nemodificat nu oferă suficientă vitamina E, fier sau acizi grași esențiali. Mai mult, metabolismul sugarilor nu poate face față nivelurilor ridicate de proteine, sodiu și potasiu din laptele de vacă nemodificat (32).

Pentru sugarii cu galactozemie sau deficit congenital de lactază, există pe piață formule pe bază de soia. Ajută în cazul alergiilor la lapte de vacă și în cazul colicilor abdominale. Rareori, sugarii care sunt alergici la laptele de vacă pot fi, de asemenea, alergici la laptele de soia. Produsele din soia nu trebuie utilizate la sugarii cu vârsta sub șase luni cu alergii alimentare.

Pentru sugarii care nu pot tolera laptele de vacă sau formulele pe bază de soia, pot fi utilizate formule cu proteine hidrolizate. Acestea conțin proteine care au fost hidrolizate - parțial sau extensiv - în dimensiuni mai mici decât cele găsite în produsele pe bază de soia. Pentru sugarii care au o alergie la proteine, formulele hidrolizate extensiv sunt o alternativă satisfăcătoare.

Formulele de aminoacizi sunt o altă opțiune pentru sugarii cu alergie severă la laptele de vacă sau care refuză să ingere cantități adecvate de formulă hidrolizată extensiv. Acestea furnizează proteine sub formă de aminoacizi liberi fără peptide.

\section{CONCLUZII}

Laptele matern rămâne standardul de aur pentru alimentație de la momentul nașterii până la 6 luni pentru sugarii sănătoși. Oferă o creștere optimă, reprezintă cel mai bun sprijin pentru dezvoltarea neurologică și ajută la dezvoltarea imunității sugarului. Pe lângă importanța nutrițională, alăptarea creează o legătură robustă între mamă și copil. Pentru sugarii care nu sunt alăptați din motive diferite, sunt disponibile formule de lapte pentru sugari. Există afecțiuni medicale în care formulele de vacă nu sunt adecvate, dar în aceste cazuri pot fi utilizate formule pe bază de soia și formule de hidrolizat de proteine. În prezent, formulele de lapte sunt sigure și realizate în conformitate cu reglementări stricte, iar producătorii de formule de lapte investesc sume considerabile în cercetare datorită dorinței de a fi cât mai aproape de compoziția laptelui matern.

Conflict of interest: none declared Financial support: none declared 


\section{BIBLIOGRAFIE}

1. Fewtrell M, Bronsky J, Campoy C, Domellöf $\mathrm{M}$, Embleton N, et al. Complementary Feeding: A Position Paper by the European Society for Paediatric Gastroenterology, Hepatology, and Nutrition (ESPGHAN) Committee on Nutrition. J Pediatr Gastroenterol Nutr. 2017 Jan;64(1):119-132.

2. EFSA Panel on Dietetic Products, Nutrition and Allergies (NDA). Scientific opinion on the appropriate age for introduction of complementary feeding of infants. EFSA J. 2009;7:1423.

3. EFSA NDA Panel (EFSA Panel on Dietetic Products, Nutrition and Allergies). Scientific opinion on nutrient requirements and dietary intakes of infants and young children in the European Union. EFSA J. 2013;11:3408.

4. Kersting M. Nutrition of the healthy baby. Food and meal related recommendations. Monatsschrift Kinderheilkunde 2001;149(2):153.

5. Guo M. Human Milk Biochemistry and Infant Formula Manufacturing Technology. Woodhead Publishing, 2014.

6. Jackson JG, Janszen DB, Lonnerdal B, Lien EL, Pramuk KP, Kuhlman CF. A multinational study of alpha-lactalbumin concentrations in human milk. J Nutr Biochem. 2004 Sep;15(9):517-21.

7. Mihatsch W, Braegger $\mathrm{C}$, Bronsky J, et al. Prevention of vitamin $\mathrm{K}$ deficiency bleeding in newborn infants: a position paper by the ESPGHAN Committee on Nutrition. J Pediatr Gastroenterol Nutr. 2016;63:123-9.

8. Braegger C, Campoy C, Colomb V, Decsi T, Domellof M, et al.; ESPGHAN Committee on Nutrition. Vitamin $D$ in the healthy European paediatric population. $J$ Pediatr Gastroenterol Nutr. 2013 Jun;56(6):692-701.

9. Nielsen SB, Reilly JJ, Fewtrell MS, Eaton S, Grinham J, Wells JC. Adequacy of milk intake during exclusive breastfeeding: a longitudinal study. Pediatrics. 2011 Oct:128(4):e907-14.

10. Martin CR, Ling PR, Blackburn GL. Review of Infant Feeding: Key Features of Breast Milk and Infant Formula. Nutrients. 2016 May $11 ; 8(5): 279$.

11. Domellöf M, Braegger C, Campoy C, Colomb V, Decsi T, et al.; ESPGHAN Committee on Nutrition. Iron requirements of infants and toddlers. J Pediatr Gastroenterol Nutr. 2014 Jan;58(1):119-29.

12. Quigley MA, Kelly YJ, Sacker A. Infant feeding, solid foods and hospitalisation in the first 8 months after birth. Arch Dis Child. 2009 Feb;94(2):148-50.

13. Muraro A, Halken S, Arshad SH, Beyer K, Dubois AE, et al.; EAACI Food Allergy and
Anaphylaxis Guidelines Group. EAACl food allergy and anaphylaxis guidelines. Primary prevention of food allergy. Allergy. 2014 May;69(5):590-601.

14. Nwaru BI, Erkkola M, Ahonen S, Kaila M, Haapala AM, et al. Age at the introduction of solid foods during the first year and allergic sensitization at age 5 years. Pediatrics. 2010 Jan;125(1):50-9.

15. lerodiakonou D, Garcia-Larsen V, Logan A, Groome A, Cunha S, et al. Timing of Allergenic Food Introduction to the Infant Diet and Risk of Allergic or Autoimmune Disease: A Systematic Review and Meta-analysis. JAMA. 2016 Sep 20;316(11):1181-1192.

16. Fleischer DM, Sicherer S, Greenhawt M, Campbell D, Chan E, et al. Consensus communication on early peanut introduction and the prevention of peanut allergy in high-risk infants. Ann Allergy Asthma Immunol. 2015 Aug;115(2):87-90.

17. Perkin MR, Logan K, Marrs T, Radulovic S, Craven J, Flohr C, Lack G; EAT Study Team. Enquiring About Tolerance (EAT) study: Feasibility of an early allergenic food introduction regimen. J Allergy Clin Immunol. 2016 May;137(5):1477-1486.e8.

18. Agostoni C, Decsi T, Fewtrell M, Goulet O, Kolacek S, Koletzko B, et al.; ESPGHAN Committee on Nutrition. Complementary feeding: a commentary by the ESPGHAN Committee on Nutrition. $J$ Pediatr Gastroenterol Nutr. 2008 Jan;46(1):99-110.

19. Szajewska H, Shamir R, Mearin L, Ribes-Koninckx C, Catassi C, et al. Gluten Introduction and the Risk of Coeliac Disease: A Position Paper by the European Society for Pediatric Gastroenterology, Hepatology, and Nutrition. J Pediatr Gastroenterol Nutr. 2016 Mar;62(3):507-13.

20. Pieścik-Lech M, Chmielewska A, Shamir R, Szajewska H. Systematic Review: Early Infant Feeding and the Risk of Type 1 Diabetes. J Pediatr Gastroenterol Nutr. 2017 Mar;64(3):454-459.

21. Rippin HL, Hutchinson J, Evans CEL, Jewell J, Breda JJ, Cade JE. National nutrition surveys in Europe: a review on the current status in the 53 countries of the WHO European region. Food Nutr Res. 2018 Apr $16 ; 62$.

22. Collell R, Closa-Monasterolo R, Ferré N, Luque V, Koletzko B, Grote V, Janas R, Verduci E, Escribano J. Higher protein intake increases cardiac function parameters in healthy children: metabolic programming by infant nutrition-secondary analysis from a clinical trial. Pediatr Res. 2016 Jun;79(6):880-8.

23. Jonsdottir $\mathrm{OH}$, Kleinman RE, Wells JC, Fewtrell MS, Hibberd PL, Gunnlaugsson G, Thorsdottir I. Exclusive breastfeeding for 4 versus 6 months and growth in early childhood. Acta Paediatr. 2014 Jan;103(1):105-11.

24. Birch EE, Hoffman DR, Castañeda YS, Fawcett SL, Birch DG, Uauy RD. A randomized controlled trial of long-chain polyunsaturated fatty acid supplementation of formula in term infants after weaning at 6 wk of age. Am J Clin Nutr. 2002 Mar;75(3):570-80.

25. Hoffman DR, Birch EE, Castañeda YS, Fawcett SL, Wheaton DH, Birch DG, Uauy $R$. Visual function in breast-fed term infants weaned to formula with or without long-chain polyunsaturates at 4 to 6 months: a randomized clinical trial. J Pediatr. 2003 Jun;142(6):669-77.

26. Verfuerden ML, Dib S, Jerrim J, Fewtrell M, Gilbert RE. Effect of long-chain polyunsaturated fatty acids in infant formula on long-term cognitive function in childhood: A systematic review and meta-analysis of randomised controlled trials. PLoS One. 2020 Nov 5;15(11):e0241800.

27. Guidance for Industry: Demonstration of the Quality Factor Requirements Under 21 CFR 106.96(i) for "Eligible" Infant Formulas. Available at: https://www.fda.gov/regulatoryinformation/search-fda-guidance-documents/ guidance-industry-demonstration-qualityfactor-requirements-under-21-cfr-10696ieligible-infant.

28. Lönnerdal B. Preclinical assessment of infant formula. Ann Nutr Metab. 2012;60(3):196-9.

29. Safe Preparation, Storage and Handling of Powdered Infant Formula Guidelines. Available at: http://www.who.int/foodsafety/ publication/micro/pit_quideline.pdf.

30. Amon P, Sanderson I. What is the microbiome? Arch Dis Child Educ Pract Ed. 2017 Oct;102(5):257-260.

31. Smith PA. The tantalizing links between gut microbes and the brain. Nature. 2015 Oct 15;526(7573):312-4.

32. Koletzko B, Beyer J, Brands B, Demmelmair $\mathrm{H}$, Grote V, et al.; European Childhood Obesity Trial Study Group. Early influences of nutrition on postnatal growth. Nestle Nutr Inst Workshop Ser. 2013;71:11-27. 